\title{
Surveillance \& Society \\ Reckoning with COVID, Racial Violence, and the Perilous Pursuit of Transparency
} Editorial

\section{Torin Monahan}

University of North Carolina at Chapel Hill, USA

torin.monahan@unc.edu

\begin{abstract}
This essay reflects on the many upheavals of the past year and their implications for critical scholarship on surveillance. The COVID-19 pandemic, anti-science policies, radicalized white supremacists, police killings of people of color, and the resurgence of the racial justice movement all inflect surveillance practices in the contemporary moment. In particular, today's polarized political landscape makes it difficult to condemn surveillance in the service of the public good, but irrespective of one's goals or intentions, the embrace of transparency carries its own risks. Transparency, and scientific vision more broadly, is an extension of the Enlightenment and subsequent scientific revolution, which from the start sought to advance knowledge and consolidate white power through the violent subjugation of nature, women, and racial minorities. One fundamental risk of valorizing transparency is that doing so occludes the ways that relations of domination are indelibly encoded into surveillance systems and practices. Given this, I argue that the project of decolonizing surveillance inquiry should now be our primary focus as a field.
\end{abstract}

\section{Introduction}

This was a year that saw a deadly pandemic with over 2.5 million deaths and extreme inequities in patterns of victims and their health outcomes (Johns Hopkins University 2021; COVID Tracking Project 2021). A year where people watched their loved ones die via video screens. A year where refrigerated trucks had to serve as makeshift, temporary morgues. A year where I, like so many others, could not visit ailing family members in the hospital, where we attended emotionally crushing memorial services via Zoom.

This was a year that saw rampant COVID denial, driven by President Trump and others in positions of influence but resonating deeply with conservative white populations already primed to be suspicious of governmental authorities and scientific facts. A year where flagrant noncompliance with mask-wearing guidelines was embraced by some as a sign of power, as an assertion of white privilege and control. Exposure was recast as strength and virility; precaution as feminized weakness or credulity.

This was a year that saw the brutal, insidious potential of social media platforms to fuel conspiracy theories, polarize communities, and drive people to violence. A year where disinformation became so widespread that truth lost its tenuous mooring, perhaps for good, drowned out in a sea of falsehoods. In the US, this culminated in a deadly right-wing mob attack on the Capitol, a last-ditch effort to overturn an election that would remove Trump from power. Forensic investigation of the attackers' social media streams revealed not only their premeditated violent intent but also their algorithmically charted path toward radicalization, 
whereby in the course of a few years, supporters of President Obama could be transformed into QAnon fanatics (Bellingcat Investigation Team 2021). ${ }^{1}$

This was a year that saw the police murder of George Floyd, Breonna Taylor, and hundreds of other people of color. These killings sparked a resurgence in the racial justice movement, not only in the US but throughout the world, leading to solidarity protests, demands for accountability, and popular calls to defund the police. Across institutions, from entertainment to academia, from technology companies to sports franchises, organizations scrambled to issue statements of support for racial justice and implement diversity, equity, and inclusion policies to actualize change. Efforts to reform and diversify institutions gained more traction than perhaps at any time since the Civil Rights Movement (Morris 2021; The White House 2021).

\section{Tracking During the Pandemic (and Beyond)}

One year ago, in an editorial in this journal, Martin French and I grappled with what the then-emerging pandemic might mean for the field of surveillance studies (French and Monahan 2020). We noted the racialization of threat categories, along with the dangers of disinformation. We also flagged the ways that "this global health crisis is being used to normalize oppressive surveillance measures, perhaps making them seem more palatable or even necessary as insurance against unknown future contagions or threats" (6). In many respects, our forecasts were, unfortunately, correct.

At least initially, when it still seemed possible to contain the virus' spread, many countries implemented travel bans and launched substantial contact-tracing systems. Some countries, like Australia, even enforced - and still do enforce- hotel-based quarantines for incoming travelers, along with accompanying guards to (attempt to) ensure compliance (Mao 2021). Contact-tracing functionality has now been integrated into Apple's and Google's mobile phone software (McCall, Skutsch, and Honey-Roses 2021). Universities and other institutions are also requiring compliance with COVID-testing protocols and contact-tracing surveillance systems. Additionally, and not inconsequentially, the normalization of remote working, at least for many service-based occupations, has brought with it a raft of new workplace surveillance to verify identities biometrically, record video meetings, and measure productivity more generally. Regardless of the immediate need for or reasonableness of any of these measures, surveillance studies scholars should easily be able to predict how the exceptional will become routine and how "mission creep" will push these capabilities into new formations of control (Kitchin 2020; Leslie 2020; Taylor et al. 2020).

Tracking-based surveillance projects have also acquired moral resonance during these fraught times. Particularly as the public's attention has been concentrated on the dangerousness of individuals asserting their "freedoms" through mass-congregation, the tracking of mobile phones, for instance, has become a way of visualizing both selfishness, disease spread, and even insurrection. One widely circulated visualization tracked the mobile phones of individuals who were celebrating spring break on a single beach in Fort Lauderdale, Florida, in 2020 (Tectonix 2020). In the weeks after spring break, those phones moved across the entire East Coast and beyond, and an animated visualization of that movement showed a dense orange glow against a black backdrop of a map of the US - a representation of presumed mobile disease vectors (see Figure 1). No special consent was required for the location-based surveillance that fed this visualization, as the functionality is simply built into popular apps installed on most people's phones (O'Sullivan and Barrett 2020). ${ }^{2}$ In a more recent instance, the mobile phones of right-wing rioters at the US Capitol were similarly tracked, showing their movements throughout the day, whether they trespassed into the Capitol building itself, and the home locations to which they returned, thereby allowing for fairly easy identification

\footnotetext{
1 This path toward far-right radicalization is often referred to as "redpilling," which is a process whereby individuals come to believe "a truth that is counterfactual to mainstream belief, which may include white supremacy, Holocaust denial, the danger that immigration posits for white Americans, the oppression of men by feminists, and so forth" (Lewis and Marwick 2017: 19).

2 The mobility data behind this visualization by Tectonix (https://www.tectonix.com/ [accessed February 18, 2021]) were provided by the software company X-Mode Social (https://xmode.io/) [accessed February 18, 2021]).
} 
(Warzel and Thompson 2021). ${ }^{3}$ As a New York Times story recounted: "Key to bringing the mob to justice has been the event's digital detritus: location data, geotagged photos, facial recognition, surveillance cameras and crowdsourcing" (Warzel and Thompson 2021). Mobile phone and social media data, especially from the insecure and now de-platformed site Parler (Koebler and Cox 2021), afford such investigation, which in the current climate seems justified, no matter the method.

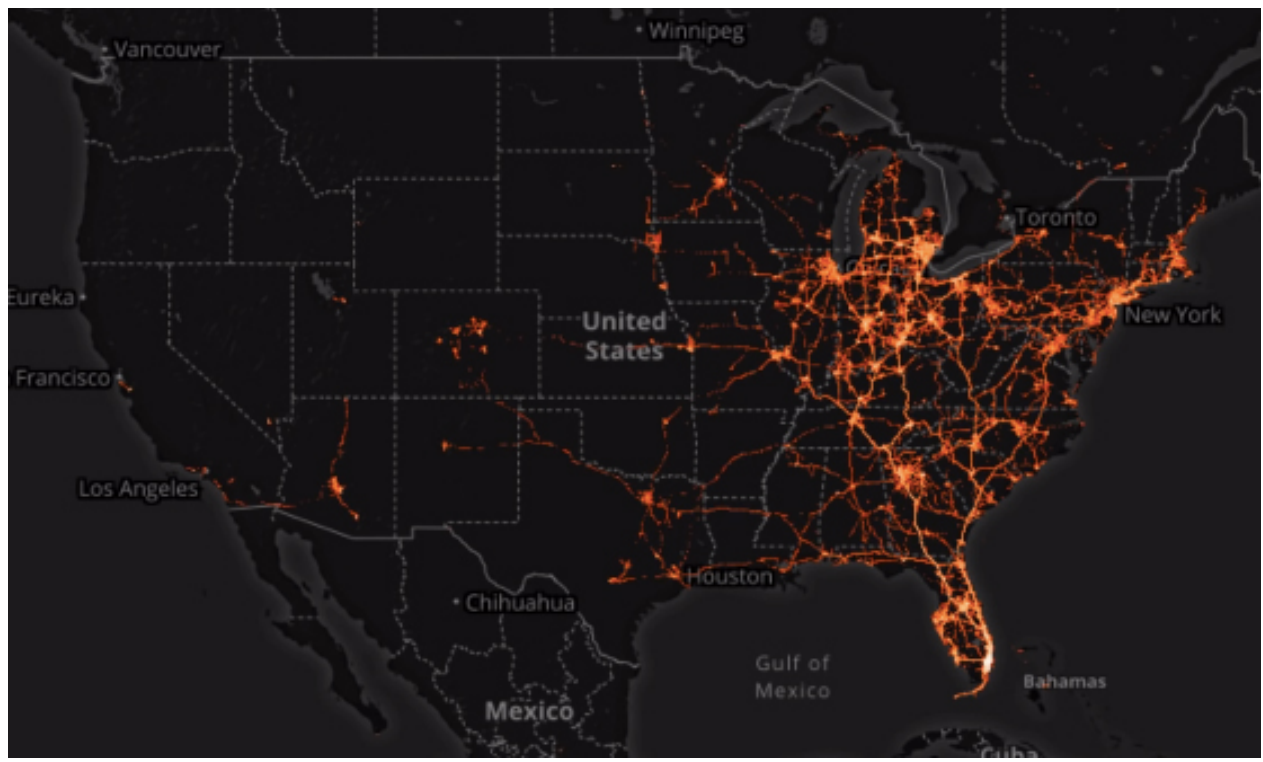

Figure 1: "Spring Break vs. COVID-19," Tectonix (2020). Image used with permission.

\section{Unsettling Transparency}

Today's polarized political landscape makes it difficult to condemn surveillance in the service of the public good, but irrespective of one's goals or intentions, there is a deeper assumption built into how groups latch onto surveillance as a response to infractions. Quite clearly, transparency is assumed to be an essential condition for justice, shaming, or accountability. What does it mean, though, that we have this impulse toward transparency? What does it occlude? What are its limitations or dangers? While such questions cannot be explored in great depth in a single editorial, I believe that we should probe them reflexively, looking toward what might be the field's complicity in the destructive surveillance imperatives that scholars are typically inclined to critique.

In some respects, as Byung-Chul Han (2015) has claimed, transparency has become an ideology that demands compulsory conformity and disclosure from subjects and, in the process, solidifies pervasive systems of control. Expectations for transparent sharing among people, Clare Birchall (2017: 2-3) argues, condition "an antipoliticized public" that is apportioned "responsibility without power." When transparency operates as the master protocol for digitally mediated existence, opacity becomes anathema. Rachel Hall (2015) further details the ways that in the post-9/11 context, opacity has become coded (again) as racialized threat, which is a situation that subsequently provokes moves of voluntary transparency on the part of individuals to perform their status as compliant, non-threating subjects. Clearly, social identities and positions substantially affect one's ability to convincingly perform such transparent innocence. Not only are

\footnotetext{
${ }^{3}$ Media forensic efforts of this sort, as Kelly Gates (2020) reminds us, perform a sublimating function of mitigating anxiety through the fabrication of empirical certainties while leaving the grounds of larger insecurities and conflicts uninterrogated. Surveillance evidence becomes harnessed not so much as discrete data but instead as nested components in a larger, enticing narrative structure.
} 
nonwhite subjects routinely coded as opaque risk, but so too are gender nonconforming persons marked as suspect or deviant (Beauchamp 2019; Fischer 2019). ${ }^{4}$

When transparency is mobilized for the governance of institutions, though, actors readily game "transparency optics" to selectively disclose information, manage its reception, and intentionally obscure or restrict information that could lead to robust accountability (Grinberg 2019; see also Brucato 2015). Because of this, as Tod Chambers (2017) has discussed in his work on medical ethics, gestures of transparency (e.g., the signing of informed consent forms, the formation of ethics advisory boards) often serve as a kind of "moral misdirection" that, much like a magician's trick, manipulates audiences into thinking that issues such as conflicts of interest have been resolved, when in fact the underlying problems remain. With algorithmic systems, as Mike Ananny and Kate Crawford (2018: 984) have explored, the transparency impulse may be especially misguided because "it cannot be used to explain - much less govern-a distributed set of human and non-human actors whose significance lies not internally but relationally." 5

For surveillance studies in particular, one fundamental risk of valorizing transparency is that it supports a social determinist posture with respect to surveillance. Rather than confront the relations of domination indelibly encoded into surveillance systems and practices, this stance encourages a belief in the possibility of neutral or beneficial surveillance. Articulations of such social determinism abound in surveillance studies, from Gary Marx's (2015: 733) notion that "surveillance is neither good nor bad but context and comportment make it so," to David Lyon's view that surveillance can be positioned along a spectrum from benevolent care to malevolent control (Lyon 2018; for a detailed critique, see Harding 2018a, 2018b). ${ }^{6}$ Even the popularity of concepts like sousveillance betrays a desire in the field for forms of surveillance that can be empowering or liberating in some way, as if surveillance were a neutral tool rather than an irredeemably tainted and corrupt apparatus of power. ${ }^{7}$

An alternative way of looking at transparency is to see it as an extension of the Enlightenment and subsequent scientific revolution, which from the start sought to advance knowledge and consolidate white power through the violent subjugation of nature, women, and racial minorities. Francis Bacon, after all, was especially fond of describing the ways that nature should be tortured, raped, and enslaved so that "she" would reveal her secrets to men of science (Merchant 1980). Seventeenth-century European science was put into the service of colonial missions to better understand diseases and extract raw materials from the colonies, with science funded from the outset as a tool of capture and conquest (Hess 1995). More than that, as Michael Adas (1989) has shown, colonial powers assessed how "civilized" other cultures were by how well they measured up to Western science and technology, thereby justifying so-called civilizing missions

\footnotetext{
${ }^{4}$ As Toby Beauchamp (2019: 2) argues with respect to transgender individuals, such detection is never an impartial or apolitical process, rather surveillance and security "produce the very categories and figures of gendered deviance that they purport to simply identify."

5 Ananny and Crawford's article provides a detailed typology of the limitations of transparency, including an exploration of the harms that may result from attempts to actualize this ideal (Ananny and Crawford 2018; see also Monahan 2018).

${ }^{6}$ Some of my earlier published thought experiments also played with the possibility of empowering surveillance (e.g., Monahan 2010), so I fully understand the analytic appeal of this move.

${ }^{7}$ That said, the concept of sousveillance is fundamentally unsound in other ways too. First, it is a misnomer. As David Murakami Wood and I write: "If surveillance is about the exercise of influence or control, then sousveillance (a view from below) would necessarily become surveillance at the moment that such influence or control were achieved, regardless of one's status position" (Monahan and Murakami Wood 2018b: 333). Second, as originally deployed by Steve Mann, sousveillance reproduces racialized violence. Some of the early footage from Mann's project shows him (a white academic man) targeting black women working in low-wage service sector jobs and thrusting his camera in their faces in the service of his critical performances (e.g., http://wearcam.org/shootingback/cvs.mpg [accessed February 22, 2021]). I wonder, what stain was produced by the violence of the concept's original deployment? What responsibility do we have now, especially now, to remember and confront these origins? (See also Borradaile and Reeves 2020; Newell 2020; Monahan 2006; Wilson and Serisier 2010).
} 
when Others were found — or presumed — to be inferior (see also Hess 1995: 85). ${ }^{8}$ Now-discredited sciences of racial difference, such as eugenics, operated in a similar register to shore up white supremacy by asserting the constructed "objective" inferiority of people of color (Cole 2001; Harding 1993; Kevles 1995). ${ }^{9}$ Over time, as Donna Haraway (1991: 188-89) relates, modern science mutated but maintained this aggressive orientation to support "militarism, capitalism, colonialism, and [white] male supremacy" while hiding behind "the god-trick of seeing everything from nowhere." Transparency, and scientific vision more broadly, is not a neutral or benign means of pursuing knowledge but is a way of asserting power and control over a bodies, territories, and systems. The social sciences are also implicated in this larger enterprise, whether by directly supporting colonial, imperial, and capitalist projects or by perpetuating myths of objective science and placeless knowledge (Harding 1998; Lewis 1973; Price 2016; Restivo 1988).

\section{Decolonizing Surveillance Inquiry}

By drawing upon recent black studies scholarship, we can find a complementary critique of modern liberal societies as both founded upon and reproductive of relations of racial subjugation, exclusion, and eradication (Hartman and Wilderson 2003; Sexton 2008; Sharpe 2016). This position holds that slavery and colonization should be understood as constitutive features of the contemporary social order, not as simply sordid historical exceptions to that order (Spillers 1987; Wilderson III 2010). As such, remedies that appeal to the law or to institutional reform are in friction with a regime of legal universality that is predicated on racial exclusion (Mills 1997; Weheliye 2014). Likewise, as Simone Browne (2015) argues, surveillance is woven into and inseparable from the history of slavery and anti-nonwhite racism (see also Bahrainwala 2019; Cahill 2018; Dubrofsky and Magnet 2015; Monahan 2020). ${ }^{10}$ Therefore, I would assert, a critique of surveillance cannot be founded on a call for more or different surveillance because that would leave the dominant rationalities of racialized surveillance intact. ${ }^{11}$ It would perform a similar sort of "god trick" that positions mechanisms of racial domination as nothing more than apolitical tools, when in actuality they are central supports of a white supremacist racial order. ${ }^{12}$

\footnotetext{
${ }^{8}$ For those who might rebut that early science, in its abstract form, was simply pure knowledge that was repurposed for political or economic ends, a compelling case has been made that even Isaac Newton, with his theories of mechanics, was essentially working toward the advancement of industrial capitalist interests in mining, ballistics, and navigation (Hessen 1971).

${ }^{9}$ Disturbingly, these narratives linger on in contemporary medicine that still often presumes that black people have inferior lung capacity (Braun 2014), or that they do not feel pain as acutely as whites (Villarosa 2019), or that their assumed racial differences necessitate their inclusion in COVID-19 vaccine trials (Fisher 2020). Furthermore, contemporary biometric surveillance systems often replicate earlier assumptions about racial difference and inferiority (Heynen 2020; Gates 2011; Magnet 2011).

${ }^{10}$ The long-term implications of surveillance-facilitated racism lead to what Oscar Gandy has identified as cumulative disadvantage: "the ways in which historical disadvantages cumulate over time, and across categories of experience" (Gandy Jr. 2018: 363; see also Gandy Jr and Nemorin 2019).

${ }^{11}$ I am reminded here of Audrey Lorde's (2007: 110-12) incisive observations: "What does it mean when the tools of a racist patriarchy are used to examine the fruits of that same patriarchy? It means that only the most narrow parameters of change are possible and allowable... For the master's tools will never dismantle the master's house. They may allow us temporarily to beat him at his own game, but they will never enable us to bring about genuine change."

12 One can find an adjacent argument in James Harding's critique of Lyon's praise for "caring" forms of surveillance. For Harding, discourses of "care" become an apology for and enabler of oppressive surveillance. He writes:
}

Modeling an understanding of surveillance after the Christian notions of "watchfulness" or "care" rationalizes away and thus provides cover for the potential for abuse and corruption that the powerful technologies of surveillance always produce... [We should] recognized that surveillance is first and foremost - always already - a punitive measure, and that when all is said and done, biblical metaphors tend to obscure this basic historical fact (Harding 2018a: 39, 64). 
This critique could appear to be guilty of invoking and privileging a humanistic disciplinary orientation in contradistinction to the dominant ones that have most strongly guided the field's development (e.g., sociology, criminology). I am sympathetic to this issue and have no interest in advocating for the substitution of one dominant disciplinary frame with another. After all, disciplinary diversity is what animates the field, giving it its vibrancy and fostering a sense of participating in a larger shared enterprise. ${ }^{13}$ That said, the field is not simply comprised of a mosaic of approaches because, in fact, the disciplinary orientations of the original work in the field have exerted an outsized and often unacknowledged influence on its trajectory, on its guiding questions and concerns, and on its favorite concepts (Harding 2018a; Heynen and van der Meulen 2016; Monahan 2011; Monahan and Murakami Wood 2018c).

Perhaps at another time these would seem to be merely academic debates, but the past year of upheaval has brought the politics of scholarly work into sharper focus. Crises have a way of distilling problems: they highlight deficiencies and recalibrate priorities. In my view, if the present moment signifies anything for the field, it should be that the project of decolonizing surveillance studies and its aligned fields has barely begun. Decolonizing surveillance studies would mean a complete realignment of the field to foreground racial inequalities and colonial legacies while also shaking up established knowledge hierarchies to center community-based expertise and the contributions of underrepresented and intersectionally positioned scholars. ${ }^{14}$ This project requires not just token mention or occasional treatments in special journal issues or sections, as impressive and necessary as those provocations are. ${ }^{15}$ Instead, it demands concentrated, continuous, dedicated work (Parker et al. 2018). It demands questioning our individual research programs, confronting the shortcomings in our previous scholarship (my own included), and holding each other to account (Strega and Brown 2015). It demands concerted effort to make space for new voices and new ways of speaking (Battiste 2008; Mokos forthcoming).

Decolonizing surveillance studies should also imply a critical interrogation of our conceptual apparatuses, methodological approaches, and topics of study. As Antonia Darder (2018: 102) eloquently asserts: "the overarching purpose of a decolonizing methodology is to provide an emancipatory reformulation of the conceptual or ideological interrelationships that exist between theoretical explanations and practical applications within specific fields or areas of study and struggle." In this editorial, I have chosen to underscore the field's easy slippage into the celebration of surveillance-enabled transparency (provided we believe that such transparency will be corrective in some way), which is a tendency that may inadvertently affirm surveillance logics while obscuring their racist origins and legacies. ${ }^{16}$ The prevalence and resilience of scientism in the field's methodologies also lends itself to a detachment that is better suited to objectify research subjects than partner with them (cf. Smith 2012), more likely to impose frameworks than allow

\footnotetext{
13 As David Murakami Wood and I write in Surveillance Studies: A Reader: "Perhaps the field's defining feature is its search for commonalities among tensions in disciplinary approaches to surveillance. This is the reason we prefer to call surveillance studies a 'transdisciplinary field.' It draws its strength and forms its identity from shared general concerns and productive frictions among disciplines, all the while fostering departures and innovations" (Monahan and Murakami Wood 2018a: xxi).

14 Moreover, as Bryce Newell (2019: 716, emphasis added) writes, decolonial surveillance-studies scholarship "recognizes and problematizes colonial histories and practices and their continuing influence on surveillance in modern life."

${ }^{15}$ See, for instance, the vital Surveillance \& Society Dialogue section on "Decolonizing Surveillance Studies" (Vol. 17, Issue 5), which formalized these concerns and charted an initial path for further transformation (Arora 2019; Fang 2019; Glasbeek, Roots, and Alam 2019; McKinson 2019; Newell 2019; Ogasawara 2019; Schnepf 2019; Sung 2019).

16 David Murakami Wood (2015: 294) has made related observations about the inadequacy of transparency efforts for intervening in conditions of structural violence:

Simple 'transparency' of the state's security or resilience operations is not in itself a solution... [because, in part,] the contemporary scopic regime... serves to conceal the structural violence within the notion of the public. And, as the ongoing protests by African Americans across the United States in response to police killings are showing, this remains the case, unless and until those subjects of security are prepared to contravene the 'civilized' norms of the public, and neither simply reveal it nor just hide from it..., but directly oppose its structural violence through riot and revolt.
} 
them to emerge collaboratively (cf. Monahan 2011). ${ }^{17}$ Finally, especially pressing right now, our selection of research topics is itself a political choice that can either work toward decolonizing institutions and academic fields or, alternately, can subtend the status quo (Richardson 2018; Woodhouse et al. 2002). Although the academy is fairly well sensitized to these issues, or is rapidly becoming so, it is abundantly, painfully clear that the current status quo in larger society is one of white supremacy, patriarchy, and festering intolerance for racial, gender, and sexual difference. Dismantling this status quo is the social imperative of our time.

\section{Acknowledgments}

This past year has introduced a host of challenges for the smooth operation of an open-access, non-profit, volunteerbased journal like Surveillance \& Society. I would like to explicitly acknowledge and thank the core editorial team for its commitment, labor, and camaraderie in keeping the journal's processes on track and on schedule. Doing so is a testament to the profound collegiality and mutual support that characterizes our field. The core team members are Philip Boyle, Susan Cahill, Kathleen M. Kuehn, David Murakami Wood, Bryce Newell, Courtlyn Pippert, Joshua Reeves, Alana Saulnier, Elaine Schnabel, Scott Thompson, Dean Jonathon Wilson, and J. Macgregor Wise. Additionally, I would like to thank the journal's reviewers for their invaluable assistance and its authors for their empathetic patience as we have worked through our individual and shared difficulties. I am deeply moved and impressed by the community we have created.

\section{References}

Adas, Michael. 1989. Machines as the Measure of Men: Science, Technology, and Ideologies of Western Dominance. Ithaca, NY: Cornell University Press.

Ananny, Mike, and Kate Crawford. 2018. Seeing without Knowing: Limitations of the Transparency Ideal and Its Application to Algorithmic Accountability. New Media \& Society 20 (3): 973-989.

Arora, Payal. 2019. General Data Protection Regulation - a Global Standard? Privacy Futures, Digital Activism, and Surveillance Cultures in the Global South. Surveillance \& Society 17 (5): 717-725.

Bahrainwala, Lamiyah. 2019. Blind Submission. Communication, Culture and Critique 12: 519-534.

Battiste, Marie. 2008. Research Ethics for Protecting Indigenous Knowledge and Heritage: Institutional and Researcher Responsibilities. In Handbook of Critical and Indigenous Methodologies, edited by N. K. Denzin, Y. S. Lincoln and S. L. Tuhiwai. Berkeley, CA: Sage, 497-509.

Beauchamp, Toby. 2019. Going Stealth: Transgender Politics and U.S. Surveillance Practices. Durham: Duke University Press. Bellingcat Investigation Team. 2021. The Journey of Ashli Babbitt. Available from https://www.bellingcat.com/news/2021/01/08/the-journey-of-ashli-babbitt/ [accessed February 18, 2021].

Birchall, Clare. 2017. Shareveillance: The Dangers of Openly Sharing and Covertly Collecting Data. Minneapolis: University of Minnesota Press.

Borradaile, Glencora, and Joshua Reeves. 2020. Sousveillance Capitalism. Surveillance \& Society 18 (2): $272-275$.

Braun, Lundy. 2014. Breathing Race into the Machine: The Surprising Career of the Spirometer from Plantation to Genetics. Minneapolis: University of Minnesota Press.

Browne, Simone. 2015. Dark Matters: On the Surveillance of Blackness. Durham: Duke University Press.

Brucato, Ben. 2015. The New Transparency: Police Violence in the Context of Ubiquitous Surveillance. Media and Communication 3 (3): 39-55.

Cahill, Susan. 2018. Visual Art, Corporeal Economies, and the "New Normal" of Surveillant Policing in the War on Terror. Surveillance \& Society 17 (3/4): 252-266.

Chambers, Tod. 2017. The Illusion of Transparency. American Journal of Bioethics 17 (6): 32-33.

Cole, Simon A. 2001. Suspect Identities: A History of Fingerprinting and Criminal Identification. Cambridge, MA: Harvard University Press.

COVID Tracking Project. 2021. The Covid Racial Data Tracker. Available from https://covidtracking.com/race [accessed February $18,2021]$.

Darder, Antonia. 2018. Decolonizing Interpretive Research: Subaltern Sensibilities and the Politics of Voice. Qualitative Research Journal 18 (2): 94-104.

Dubrofsky, Rachel E., and Shoshana Amielle Magnet, eds. 2015. Feminist Surveillance Studies. Durham: Duke University Press.

Fang, Karen. 2019. Rethinking the Orwellian Imaginary through Contemporary Chinese Fiction. Surveillance \& Society 17 (5): $738-742$.

${ }^{17}$ Drawing upon the field of science and technology studies, I use the term scientism to refer to research "that aspires toward value-free, objective findings while denying that this is a biased, partial, and exclusionary form of knowledge production" (Monahan and Fisher 2010: 370). 
Fischer, Mia. 2019. Terrorizing Gender: Transgender Visibility and the Surveillance Practices of the US Security State. Lincoln, NE: University of Nebraska Press.

Fisher, Jill A. 2020. Inclusive Vaccine Trials Are Vital, but Let's Not Boost Biological Views of Race. TruthOut, December 27. Available from https://truthout.org/articles/inclusive-vaccine-trials-are-vital-but-lets-not-boost-biological-views-of-race/ [accessed February 22, 2021].

French, Martin, and Torin Monahan. 2020. Dis-Ease Surveillance: How Might Surveillance Studies Address Covid-19? Surveillance \& Society 18 (1): 1-11.

Gandy Jr, Oscar H., and Selena Nemorin. 2019. Toward a Political Economy of Nudge: Smart City Variations. Information, Communication \& Society 22 (14): 2112-2126.

Gandy Jr., Oscar H. 2018. Coming to Terms with Chance: Engaging Rational Discrimination and Cumulative Disadvantage. In Surveillance Studies: A Reader, edited by T. Monahan and D. Murakami Wood. New York: Oxford University Press, 361-364.

Gates, Kelly. 2011. Our Biometric Future: Facial Recognition Technology and the Culture of Surveillance. New York: New York University Press.

2020. Media Evidence and Forensic Journalism. Surveillance \& Society 18 (3): 403-408.

Glasbeek, Amanda, Katrin Roots, and Mariful Alam. 2019. Postcolonialism, Time, and Body-Worn Cameras. Surveillance \& Society 17 (5): 743-746.

Grinberg, Daniel. 2019. Tracking Movements: Black Activism, Aerial Surveillance, and Transparency Optics. Media, Culture \& Society 41 (3): 294-316.

Hall, Rachel. 2015. The Transparent Traveler: The Performance and Culture of Airport Security. Durham: Duke University Press.

Han, Byung-Chul. 2015. The Transparency Society. Stanford: Stanford University Press.

Haraway, Donna J. 1991. Simians, Cyborgs, and Women: The Reinvention of Nature. New York: Routledge.

Harding, James M. 2018a. Performance, Transparency, and the Cultures of Surveillance. Ann Arbor: University of Michigan Press. - 2018b. Picking the Speck and Missing the Beam in the Eye of Surveillance: On the Failure to See Eye to Eye with David Lyon. Surveillance \& Society 16 (4): 554-567.

Harding, Sandra. 1998. Is Science Multi-Cultural?: Postcolonialisms, Feminisms, and Epistemologies. Bloomington: Indiana University Press.

Harding, Sandra G., ed. 1993. The "Racial" Economy of Science: Toward a Democratic Future. Bloomington: Indiana University Press.

Hartman, Saidiya V., and Frank B. Wilderson. 2003. The Position of the Unthought. Qui Parle 13 (2): $183-201$.

Hess, David J. 1995. Science and Technology in a Multicultural World: The Cultural Politics of Facts and Artifacts. New York: Columbia University Press.

Hessen, Boris. 1971. The Social and Economic Roots of Newton's Principia. New York: Howard Fertig.

Heynen, Robert. 2020. Biometric Aesthetics. PUBLIC: Art/Culture/Ideas 30 (60): 108-125.

Heynen, Robert, and Emily van der Meulen. 2016. Gendered Visions: Reimagining Surveillance Studies. In Expanding the Gaze: Gender and the Politics of Surveillance, edited by E. van der Meulen and R. Heynen. Toronto: University of Toronto Press, 3-32.

Johns Hopkins University. 2021. Covid-19 Dashboard by the Center for Systems Science and Engineering (Csse) at Johns Hopkins University (Jhu). Available from https://coronavirus.jhu.edu/map.html [accessed March 4, 2021].

Kevles, Daniel J. 1995. In the Name of Eugenics: Genetics and the Uses of Human Heredity. Cambirdge, MA: Harvard University Press.

Kitchin, Rob. 2020. Civil Liberties or Public Health, or Civil Liberties and Public Health? Using Surveillance Technologies to Tackle the Spread of Covid-19. Space and Polity 24 (3): 362-381.

Koebler, Jason, and Joseph Cox. 2021. Archivists Are Mining Parler Metadata to Pinpoint Crimes at the Capitol. Vice.com, January 12. Available from https://www.vice.com/en/article/qipevv/archivists-parler-capitol-hill-crimes [accessed February 18, 2021].

Leslie, David. 2020. Tackling Covid-19 through Responsible Ai Innovation: Five Steps in the Right Direction. Harvard Data Science Review (2020). Available from https://papers.ssrn.com/sol3/papers.cfm?abstract id=3652970 [accessed February 24, 2021].

Lewis, Diane. 1973. Anthropology and Colonialism. Current Anthropology 14 (5): 581-602.

Lewis, Rebecca, and Alice E. Marwick. 2017. Taking the Red Pill: Ideological Motivations for Spreading Online Disinformation. Understanding and addressing the disinformation ecosystem:18-22. Available from https://firstdraftnews.org/wpcontent/uploads/2018/03/The-Disinformation-Ecosystem-20180207-v2.pdf [accessed February 23, 2021].

Lorde, Audre. 2007. Sister Outsider: Essays and Speeches. Berkeley: Crossing Press.

Lyon, David. 2018. God's Eye: A Reason for Hope. Surveillance \& Society 16 (4): 546-553.

Magnet, Shoshana Amielle. 2011. When Biometrics Fail: Gender, Race, and the Technology of Identity. Durham: Duke University Press.

Mao, Frances. 2021. Covid: Why Australia's 'World-Class' Quarantine System Has Seen Breaches. BBC News, February 8. Available from https://www.bbc.com/news/world-australia-55929180 [accessed February 18, 2021].

Marx, Gary T. 2015. Surveillance Studies. In International Encyclopedia of the Social \& Behavioral Sciences, edited by J. D. Wright. E-book: Elsevier, 733-741.

McCall, Michael K, Margaret M Skutsch, and Jordi Honey-Roses. 2021. Surveillance in the Covid-19 Normal: Tracking, Tracing, and Snooping-Trade-Offs in Safety and Autonomy in the E-City. International Journal of E-Planning Research (IJEPR) 10 (2): $27-44$. 
McKinson, Kimberley D. 2019. Black Carcerality and Emancipation in Postcolonial Jamaica. Surveillance \& Society 17 (5): 734 737.

Merchant, Carolyn. 1980. The Death of Nature: Women, Ecology, and the Scientific Revolution. San Francisco: Harper \& Row.

Mills, Charles W. 1997. The Racial Contract. Ithaca: Cornell University Press.

Mokos, Jennifer T. forthcoming. Engaging the Complexities of Community: Conflict and Difference in Community-Engaged Research. GeoJournal.

Monahan, Torin. 2006. Counter-Surveillance as Political Intervention? Social Semiotics 16 (4): 515-534.

- 2010. Surveillance as Governance: Social Inequality and the Pursuit of Democratic Surveillance. In Surveillance and Democracy, edited by K. D. Haggerty and M. Samatas. New York: Routledge, 91-110.

2011. Surveillance as Cultural Practice. The Sociological Quarterly 52 (4): 495-508.

2018. Algorithmic Fetishism. Surveillance \& Society 16 (1): 1-5.

2020. The Arresting Gaze: Artistic Disruptions of Antiblack Surveillance. International Journal of Cultural Studies 23 (4): 564-581.

Monahan, Torin, and Jill A. Fisher. 2010. Benefits of "Observer Effects": Lessons from the Field. Qualitative Research 10 (3): 357-376.

Monahan, Torin, and David Murakami Wood. 2018a. Introduction: Surveillance Studies as a Transdisciplinary Endeavor. In Surveillance Studies: A Reader, edited by T. Monahan and D. Murakami Wood. New York: Oxford University Press, xixxxxiv.

2018b. Resistance and Opposition. In Surveillance Studies: A Reader, edited by T. Monahan and D. Murakami Wood. New York: Oxford University Press, 331-333. , eds. 2018c. Surveillance Studies: A Reader. New York: Oxford University Press.

Morris, Aldon. 2021. From Civil Rights to Black Lives Matter. Scientific American, February 3. Available from https://www.scientificamerican.com/article/from-civil-rights-to-black-lives-matter1/ [accessed February 18, 2021].

Murakami Wood, David. 2015. The in(Ter)Visible Subjects of Security and the (Im)Possibility of a 'Public'. Dialogues in Human Geography 5 (3): 291-295.

Newell, Bryce Clayton. 2019. Introduction: Decolonizing Surveillance Studies. Surveillance \& Society 17 (5):714-716. 2020. Introduction: The State of Sousveillance. Surveillance \& Society 18 (2): 257-261.

O'Sullivan, Donie, and Sofia Barrett. 2020. How the Cell Phones of Spring Breakers Who Flouted Coronavirus Warnings Were Tracked. CNN.com, April 4. Available from https://www.cnn.com/2020/04/04/tech/location-tracking-floridacoronavirus/index.html [accessed February 18, 2021].

Ogasawara, Midori. 2019. Mainstreaming Colonial Experience in Surveillance Studies. Surveillance \& Society 17 (5): 726 -729.

Parker, Patricia, Dorothy Holland, Jean Dennison, Sara H Smith, and Melvin Jackson. 2018. Decolonizing the Academy: Lessons from the Graduate Certificate in Participatory Research at the University of North Carolina at Chapel Hill. Qualitative Inquiry 24 (7): 464-477.

Price, David H. 2016. Cold War Anthropology: The Cia, the Pentagon, and the Growth of Dual Use Anthropology. Durham, NC: Duke University Press.

Restivo, Sal. 1988. Modern Science as a Social Problem. Social Problems 35 (3): 206-225.

Richardson, William Jamal. 2018. Understanding Eurocentrism as a Structural Problem of Undone Science. In Decolonising the University, edited by G. K. Bhambra, D. Gebrial and K. Nisancioglu. London: Pluto Press, 231-247.

Schnepf, J.D. 2019. Unsettling Aerial Surveillance: Surveillance Studies after Standing Rock. Surveillance \& Society 17 (5): $747-$ 751.

Sexton, Jared. 2008. Amalgamation Schemes: Antiblackness and the Critique of Multiracialism. Minneapolis: University of Minnesota Press.

Sharpe, Christina. 2016. In the Wake: On Blackness and Being. Durham: Duke University Press.

Smith, Linda Tuhiwai. 2012. Decolonizing Methodologies: Research and Indigenous Peoples. 2nd ed. London: Zed Books Ltd.

Spillers, Hortense J. 1987. Mama’s Baby, Papa's Maybe: An American Grammar Book. diacritics 17 (2): 65-81.

Strega, Susan, and Allison Brown, eds. 2015. Research as Resistance: Revisiting Critical, Indigenous, and Anti-Oppressive Approaches. 2nd ed. Toronto: Canadian Scholars' Press.

Sung, Minkyu. 2019. The Triad of Colonialism, Anti-Communism, and Neo-Liberalism: Decolonizing Surveillance Studies in South Korea. Surveillance \& Society 17 (5): 730-733.

Taylor, Linnet, Gargi Sharma, Aaron Martin, and Shazade Jameson, eds. 2020. Data Justice and Covid-19: Global Perspectives. London: Meatspace Press.

Tectonix. 2020. Spring Break vs. Covid-19. Available from https://www.tectonix.com/demonstrations.html [accessed February 19, 2021].

The White House. 2021. Fact Sheet: President Biden to Take Action to Advance Racial Equity and Support Underserved Communities. January 26. Available from https://www.whitehouse.gov/briefing-room/statementsreleases/2021/01/26/fact-sheet-president-biden-to-take-action-to-advance-racial-equity-and-support-underservedcommunities/ [accessed February 18, 2021].

Villarosa, Linda. 2019. Myths About Physical Racial Differences Were Used to Justify Slavery — and Are Still Believed by Doctors Today. New York Times, August 14. Available from https://www.nytimes.com/interactive/2019/08/14/magazine/racialdifferences-doctors.html [accessed February 22, 2021].

Warzel, Charlie, and Stuart A. Thompson. 2021. They Stormed the Capitol. Their Apps Tracked Them. New York Times, February 5. Available from https://www.nytimes.com/2021/02/05/opinion/capitol-attack-cellphone-data.html?referrer=masthead [accessed February 18, 2021]. 
Weheliye, Alexander G. 2014. Habeas Viscus: Racializing Assemblages, Biopolitics, and Black Feminist Theories of the Human. Durham: Duke University Press.

Wilderson III, Frank B. 2010. Red, White \& Black: Cinema and the Structure of U.S. Antagonisms. Durham, NC: Duke University Press.

Wilson, Dean, and Tanya Serisier. 2010. Video Activism and the Ambiguities of Counter-Surveillance. Surveillance \& Society 8 (2): 166-180.

Woodhouse, Edward, David Hess, Steve Breyman, and Brian Martin. 2002. Science Studies and Activism: Possibilities and Problems for Reconstructivist Agendas. Social Studies of Science 32 (2): 297-319. 